\title{
A contribution to understanding the turbidity behaviour in an Amazon floodplain
}

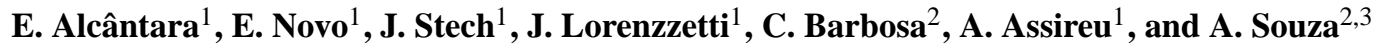 \\ ${ }^{1}$ Brazilian Institute for Space Research, Remote Sensing Division, P.O. Box 12227-010, São José dos Campos, SP, Brazil \\ ${ }^{2}$ Brazilian Institute for Space Research, Image Processing Division, P.O. Box 12227-010, São José dos Campos, SP, Brazil \\ ${ }^{3}$ ETEP Faculdades, P.O. Box 12242-800, São José dos Campos, SP, Brazil
}

Received: 29 April 2009 - Published in Hydrol. Earth Syst. Sci. Discuss.: 26 May 2009

Revised: 23 November 2009 - Accepted: 18 January 2010 - Published: 22 February 2010

\begin{abstract}
Observations of turbidity provide quantitative information about water quality. However, the number of available in situ measurements for water quality determination is usually limited in time and space. Here, we present an analysis of the temporal and spatial variability of the turbidity of an Amazon floodplain lake using two approaches: (1) wavelet analysis of a turbidity time series measured by an automatic monitoring system, which should be improved/simplified, and (2) turbidity samples measured in different locations and then interpolated using an ordinary Kriging algorithm. The spatial and temporal variability of turbidity are clearly related to the Amazon River flood pulses in the floodplain. When the water level in the floodplain is rising or receding, the exchange between the Amazon River and the floodplain is the major driving force in turbidity variability. At high-water levels, turbidity variability is controlled by Lake Bathymetry. When the water level is low, wind action and Lake Morphometry are the main causes of turbidity variability. The combined use of temporal and spatial data shows a good potential for better understanding of the turbidity behaviour in a complex aquatic system such as the Amazon floodplain.
\end{abstract}

\section{Introduction}

Turbidity is an important optical parameter in hydrological systems. High turbidity levels are associated with low sunlight penetration in the water column, which can impact photosynthesis and visibility, thereby affecting aquatic organisms at all levels in the food chain from microscopic algae

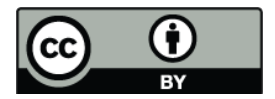

Correspondence to: E. Alcântara (enner@dsr.inpe.br) to fish. Turbidity depends essentially on the amount of suspended particulate material in the water column, which can include phytoplankton, eroded and re-suspended sediments, waste discharge, algae growth and urban runoff (Han and Rundquist, 1998; Wetzel, 2001). Furthermore, it is modulated by water flow variation. Changes in turbidity can affect both the zooplankton community (De Leo and Ferrari, 1993) and its composition (Wetzel, 2001), which can in turn eliminate sensitive organisms (Miquelis et al., 1998) and modify zooplankton taxa competition (Wetzel, 2001). Suspended particles scatter and absorb sunlight, resulting in warmer temperatures and lower concentrations of dissolved oxygen in the water column (Kirk, 1983).

The duration and intensity of a turbidity event are also important issues. A short duration of a very high level turbidity event may not be as significant as a lower level situation that lasts longer (Newcombe and Jensen, 1996). Algal turbidity can vary seasonally and with depth in a complex manner as a response to physical, chemical and biological changes in the water body. Meteorological episodes, such as cold fronts and storms, can have a strong impact on the concentration of inorganic and detritus particles from the watershed (Stech and Lorenzzetti, 1992; Tundisi et al., 2004).

Research about water quality of reservoirs and lakes has been based mostly on point station datasets or along track lines obtained during cruises (Jerosch et al., 2006). High quality in situ measurements of water parameters are usually limited and they are particularly critical for time series data and key variables (Zhang et al., 2003; George, 1997; Dekker et al., 2002; Tyler et al., 2006). The detection of trends and sudden changes in the aquatic system is dependent on both the availability of long-term time series of environmental data and their proper analysis (Stech et al., 2006). Wavelet analysis could be used to understand

Published by Copernicus Publications on behalf of the European Geosciences Union. 
(a)

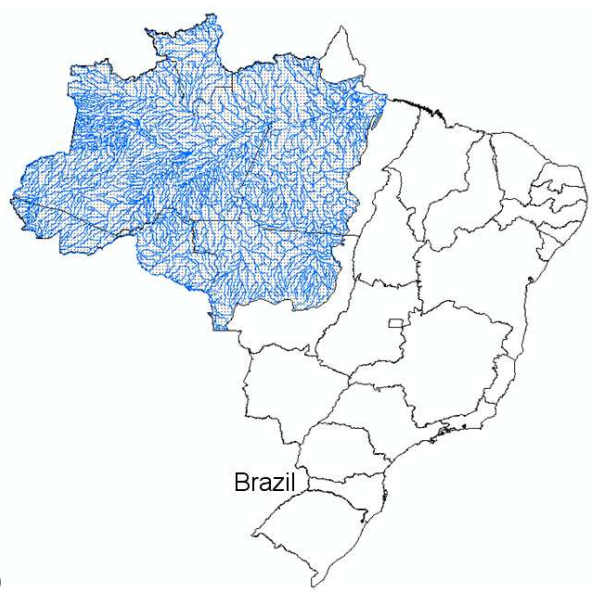

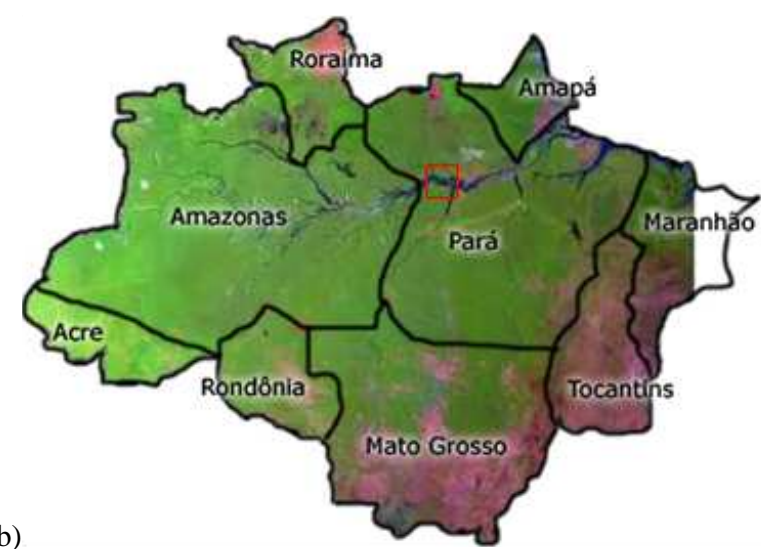

(b)

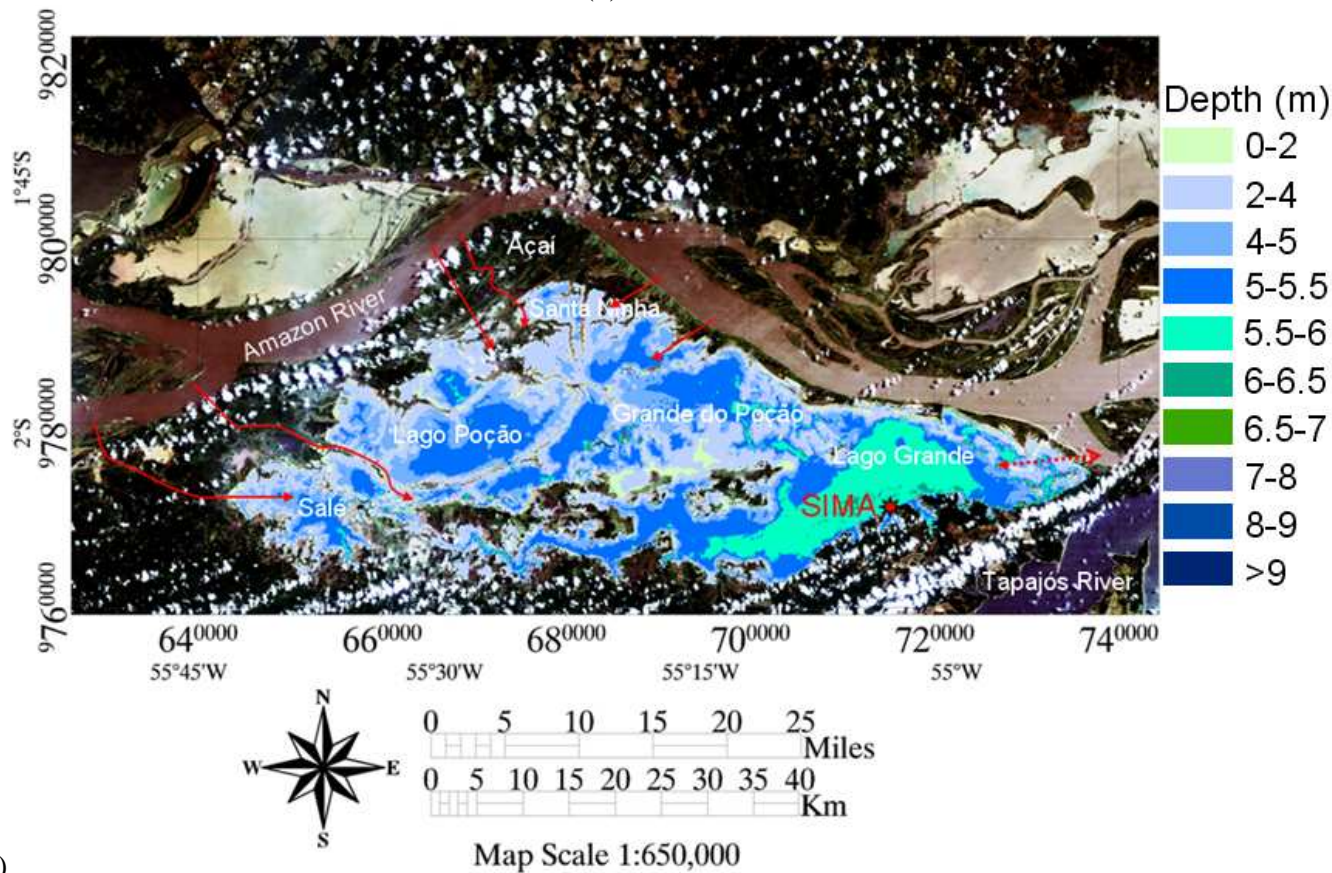

Fig. 1. (a) Location of the Legal Amazon region in Brazil, (b) Legal Amazon limits, and (c) Location of the Curuai Floodplain (red square in b) and location of the automatic environmental data collection buoy system SIMA at "Lago Grande". The arrows indicate the main channels of connection of the Amazon River floodplain.

the time-localized frequency content of the signals (Meyers et al., 1993; Kumar and Foufoula-Georgiou, 1997) but, on the other hand, the spatial variability patterns could be assessed through geostatistical analysis (Bellehumeur et al., 2000; Hedger et al., 2001).

Here, we show that the combination of a high-resolution time series and spatial data allows for a better understanding of the turbidity dynamics in the Amazon floodplain. The main objectives of this paper are to map the spatial distribution patterns of Curuaí floodplain turbidity along its hydrological cycle and to identify the controlling factors in time variability.

\section{Study site and background}

The Curuai floodplain (Fig. 1) covers an area varying from 1340 to $2000 \mathrm{~km}^{2}$ at the low and high-water levels, respectively, with a maximum volume reaching $9.3 \mathrm{~km}^{3}$ (Martinez and Le-Toan, 2006). This floodplain located $850 \mathrm{~km}$ from the Atlantic Ocean, near the city of Óbidos (Pará State, Brazil).

The Curuaí floodplain lakes are interconnected with each other and also to the Amazon River. The Curuai floodplain is controlled by the Amazon River flood pulses, which creates four water-level stages in the floodplain-river system. Water storage in the floodplain starts between November and January and lasts until May-June. The drainage phase starts in July and lasts until November. The largest exported volume 
occurs from August to October. On an annual basis, the floodplain represents a net source of water to the Amazon River (Bonnet et al., 2008).

During the 2001-2002 water cycle (Bonnet et al., 2008), it was observed that the Amazon River dominated the mixture in early January (64\%). From this date until the beginning of April, the river water contribution slightly decreased while contributions from watersheds and direct rainfall increased. By mid-April, the rainfall water constituted as much as $17 \%$. Contributions from the local upland watershed (14\%) and from the watershed located in the aquatic-terrestrial transition zone $(15 \%)$ reached their maximum by the end of February. The groundwater reservoir contribution was highest at the end of December, reaching $5 \%$ of the mixture.

The water circulation in the floodplain from the beginning of December to the end January is from west to east (Barbosa, 2005; Barroux, 2006). The main flow channels from the Amazon River to the Curuai floodplain are located at "Lago Grande", Lake "Salé", and Lake "Santa Ninha" (see Fig. 1c).

The average total annual precipitation in the Curuai floodplain is $2447 \mathrm{~mm} \mathrm{year}^{-1}$, which is much larger than the average potential evaporation of $1400 \mathrm{~mm}_{\text {year }}{ }^{-1}$ (average obtained by a time series from 1990 to 2001), with the wet season lasting from January to June and a drier season from July to December, resulting in a clear seasonal cycle controlling the water level dynamics in the floodplain (Barroux, 2006). The residence time of the riverine water within the floodplain is $5 \pm 0.8$ months, while the residence time of water from all sources is $3 \pm 0.2$ months (Bonnet et al., 2008). The lowest and highest absolute water levels recorded at the Curuaí gauging station during the 1982-2003 period were $3.03 \mathrm{~m}$ and $9.61 \mathrm{~m}$, respectively.

\section{The data set and methods}

\subsection{In situ data}

\subsubsection{Temporal domain}

The temporal variability of turbidity in the Curuai floodplain was studied using the data collected by an in-house developed anchored buoy system named Environmental Monitoring System - SIMA (Fig. 2). SIMA consists of an anchored buoy and its electronics that are instrumented with a suite of meteorological and water quality sensors (see Fig. 1 for the position of SIMA in Curuai floodplain). The following meteorological variables were collected: atmospheric pressure, relative humidity, air temperature, wind direction and intensity and incoming solar radiation (R. M. Young). The following water quality parameters were monitored: chlorophylla, $\mathrm{pH}$, turbidity, dissolved oxygen, electric conductivity, nitrate, ammonia and water temperature (YSI multi-parameter probe).

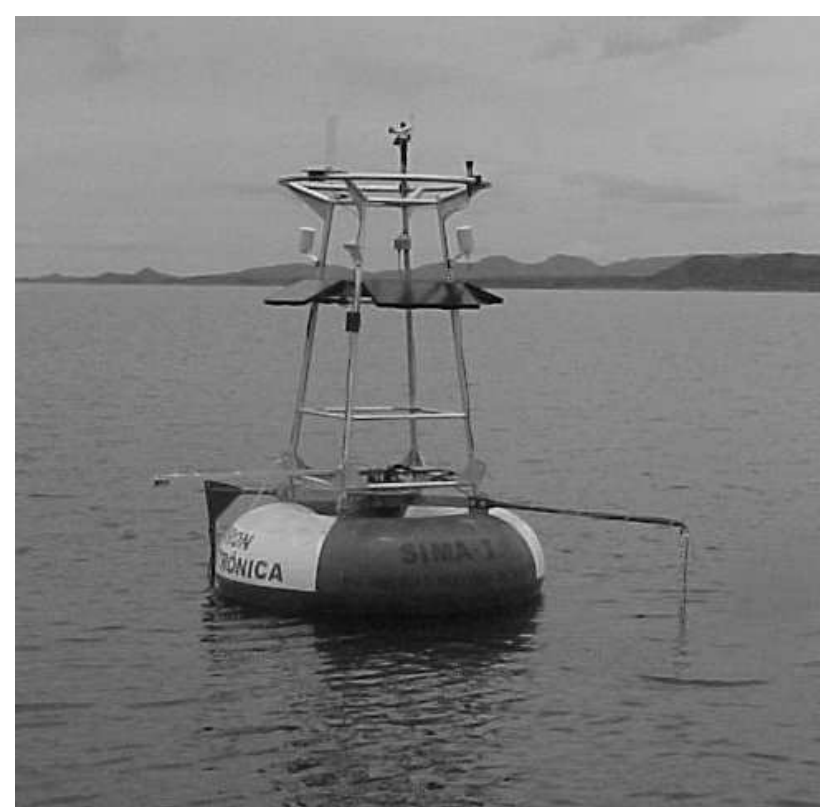

Fig. 2. Photo of SIMA installed at "Lago Grande" in the Curuai floodplain (See Fig. 1 for location).

The SIMA data were collected in preprogrammed time intervals $(1 \mathrm{~h})$ and transmitted via satellite link in quasirealtime to any user in a range of $2500 \mathrm{~km}$ from the acquisition point. In this work, we analysed the time series of hourly measurements of turbidity from 20 November 2004 to 26 April 2005. The water depth at the SIMA location was approximately $5.5 \mathrm{~m}$ at the high-water level and $1.4 \mathrm{~m}$ during the low-water level.

\subsubsection{Spatial domain}

To evaluate the spatial variability of turbidity, several field campaigns of in situ measurements (using HORIBA U-10 multi-sensor probe) were carried out from 2003 to 2004 at a number of stations (see Fig. 3 for locations) and at different Curuai floodplain lake water levels (Table 1).

The HORIBA equipment provides turbidity measurements in NTU (Nephelometric Turbidity Unit) at a resolution of 1 NTU. A calibration was performed before each day of sampling. Sampling locations were defined based on the analysis of Landsat-5 Thematic Mapper images acquired at similar floodplain stages (Barbosa, 2005). The periods of data acquisition by HORIBA and SIMA were different because the SIMA was installed at the end of 2004. The spatial distributions of turbidity samples (statistics presented in Table 1) throughout the Curuai floodplain (in standard deviation bins) are shown in Fig. 3. 

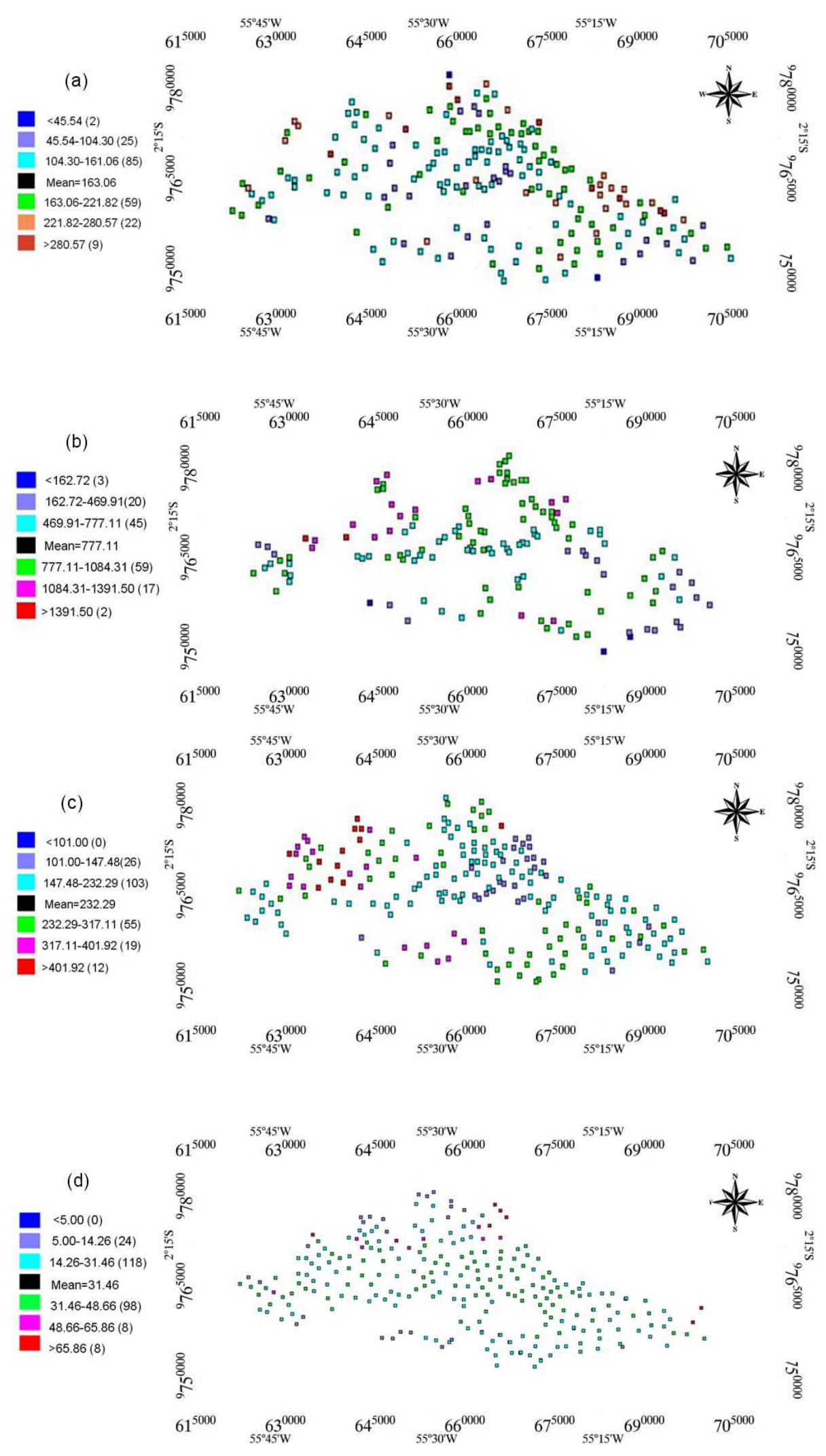

Fig. 3. Turbidity samples' distribution grouped by standard deviation bins (the numbers between parenthesis indicate the amount of samples that possess one clustering standard deviation): (a) receding water level, (b) low-water level, (c) rising water level and (d) high-water level. 
Table 1. Descriptive statistics of the in situ turbidity data (NTU).

\begin{tabular}{llccccc}
\hline $\begin{array}{l}\text { Water } \\
\text { level regime }\end{array}$ & $\begin{array}{l}\text { Period } \\
\text { of sampling }\end{array}$ & $\begin{array}{c}\text { Number } \\
\text { of samples }\end{array}$ & $\begin{array}{c}\text { Maximum } \\
\text { value }\end{array}$ & $\begin{array}{c}\text { Average } \\
\text { Rinimum } \\
\text { value }\end{array}$ & $\begin{array}{c}\text { Standard } \\
\text { deviation }\end{array}$ \\
\hline Receding water & 23 Sep 2003 - 9 Oct 2003 & 202 & 375 & 163.06 & 12 & 58.61 \\
Low-water & 19 Nov 2003 - 1 Dec 2003 & 146 & 1645 & 777.10 & 39 & 306.14 \\
Rising water & 1 Feb 2004 - 14 Feb 2004 & 215 & 569 & 232.29 & 101 & 84.61 \\
High-water & 31 May 2004 - 21 Jun 2004 & 256 & 127 & 31.46 & 5 & 17.16 \\
\hline
\end{tabular}

\subsection{Methodological approach}

\subsubsection{Time series analysis}

To analyze the temporal modes of variability of the turbidity time series, we used the Fourier Power Spectrum, Wavelet Analysis and Cross Wavelet and Coherence and Phase.

Spectrum analysis deals with the identification of cyclical patterns in the data. Data windowing was used to smooth the power spectrum, thereby reducing its variance and increasing statistical confidence also may cause spectral leakage (Press et al., 1992). To reach a compromise between strong smoothing (more confidence but stronger bias) and weak smoothing (less confidence but less bias) with an acceptable spectral leakage, we generated our power spectrum estimates using a smoothing Hamming window of variable length (Press et al., 1992).

The temporal variability of the frequency content of the turbidity time series was analysed using the Wavelet Transform (Meyers et al., 1993; Kumar and Foufoula-Georgiou, 1997; Massei et al., 2006). The decomposing an environmental time series into time-frequency space allows for the determination of both the dominant modes of variability and how those modes vary in time. The turbidity time series obtained from SIMA were analysed by continuous wavelet analysis using the Morlet wavelet as the so-called "mother wavelet".

To get a more detailed view of the importance of the wind on turbidity, which was evidenced by Alcântara et al. (2008, 2009), we applied here the cross wavelet and wavelet coherence methods in these two time series (Maraun and Kurths, 2004). The cross wavelet transform $W^{x y}$ of the two time series $x_{n}$ and $y_{n}$ is a complex function. The cross wavelet power spectrum is defined as $\left|W^{x y}\right|$, and its complex argument arg $\left(W^{x y}\right)$ can be interpreted as the local relative phase between $x_{n}$ and $y_{n}$ in the time-frequency space (Grinsted et al., 2004).

The hourly high-frequency turbidity time series allowed the study of bottom resuspension episodes that cause turbidity increases. Particularly in shallow lakes, the effects of wind inducing sediment resuspension have been shown (Booth et al., 2000). These wind-induced physical processes are important for sediment transport and can be dominant
(Lou et al., 2000). We applied the method of Booth et al. (2000) for predicting the wind-induced bottom resuspension at the SIMA location during the low-water level (from November to December).

Wind speed was measured by SIMA at $3 \mathrm{~m}$ above the water surface (Fig. 2). Correction to the standard 10-m height was made using Justus and Mikhail (1976):

$U_{10}=U_{z}\left(\frac{z}{z_{a}}\right)^{n}$,

where $U_{10}$ is the wind velocity $\left(\mathrm{ms}^{-1}\right)$ at $10 \mathrm{~m}$ height, $U_{z}$ is the wind velocity measured by SIMA at height $z, z_{a}$ is the height where the anemometer measures the wind velocity ( $3 \mathrm{~m})$ and $n$ is given by:

$n=\left[\frac{0.37-0.088 \ln U_{z}}{1-0.088 \ln \left(\frac{z_{a}}{10}\right)}\right]$.

Wind shear at the surface of the lake transfers energy and momentum to the water column, generating the mean circulation, surface and internal waves and turbulence, all of which can lead to vertical mixing (Stevens and Imberger, 1996). The minimum wind velocity needed to generate wave action that reaches the bottom and re-suspends sediment (critical windspeed, $U_{c}$ ) was calculated according to Booth et al. (2000):

$U_{c}=1.2\left\{4127\left(\frac{T_{c}^{3}}{F}\right)\right\}^{0.813}$,

where $U_{c}$ is the critical wind speed (in $\mathrm{ms}^{-1}$ ), $T_{c}$ is the critical wave period and $F$ is the effective fetch (in $\mathrm{m}$ ) calculated according to Carper and Bachmann (1984).

The basic assumption of this simple model is that the effect of waves is felt down to a depth of approximately $\frac{L}{2}$, where $L$ is the wavelength of the surface waves. So, if the water depth $(d)$ is less than $\frac{L}{2}$, there is a wave energy transfer to the bottom sediments that can result in sediment resuspension.

The critical wave period $\left(T_{c}\right)$ is given by (CERC, 1984):

$T_{c}=\left(\frac{4 \pi d}{g}\right)^{\frac{1}{2}}$ 
Table 2. Semivariogram parameters used to interpolate the turbidity.

\begin{tabular}{lccccccc}
\hline $\begin{array}{l}\text { Water } \\
\text { level }\end{array}$ & $\begin{array}{c}\text { Anisotropy } \\
\text { direction }\end{array}$ & Structure & Nugget & Sill & $>$ range & $<$ range & Model \\
\hline Rising & $94^{\circ}$ & $1^{\circ}$ & 619 & 114 & 16436 & $\varepsilon$ & Gaussian \\
& & $2^{\circ}$ & & 7770 & 17924 & 16436 & \\
& & $3^{\circ}$ & & 1480 & $\infty$ & 17924 & \\
High & $100^{\circ}$ & $1^{\circ}$ & 4.98 & 20.45 & 14637 & $\varepsilon$ & Gaussian \\
& & $2^{\circ}$ & & 119.64 & 14637 & 12003 & \\
& & $3^{\circ}$ & & 8.2 & $\infty$ & 12003 & \\
Receding & $94^{\circ}$ & $1^{\circ}$ & 401 & 229 & 12402 & $\varepsilon$ & Exponential \\
& & $2^{\circ}$ & & 3567 & 16424 & 12402 & \\
& & $3^{\circ}$ & & 261 & $\infty$ & 16242 & \\
Low & & $1^{\circ}$ & 8420 & 63595 & 9379 & $\varepsilon$ & Gaussian \\
& $94^{\circ}$ & $2^{\circ}$ & & 66885 & 9379 & 6140 & \\
& & $3^{\circ}$ & & 10430 & $\infty$ & 9379 & \\
\hline
\end{tabular}

\subsubsection{Spatial analysis}

Geostatistics is focused on the spatial context and relationships present in the data. It provides tools for the quantification and exploitation of spatial autocorrelation, as well as algorithms for data interpolation with uncertainty quantification (Isaaks and Srivastava, 1989; Goovaerts, 1997). The autocorrelation structure is used here to estimate the values of variables at points not sampled in the field (Bellehumeur et al., 2000).

A central aspect of geostatistics is the use of spatial autocovariance structures, often represented by the (semi)variogram or its cousin, the autocovariogram, which differentiates different kinds of spatial variability (Burrough, 2001). To interpolate in situ turbidity point measurements into a continuous turbidity map, we used the ordinary Kriging algorithm. The calculation of the Kriging weights was made based upon the semivariogram model.

A fitting of the semivariogram was done using several theoretical models (spherical, exponential, Gaussian, linear and power) and the weighted least-square method. The theoretical model with minimum standard error was chosen for further analysis.

Theoretical semivariogram models employ three main coefficients scaling the fit to the experimental semivariograms: (i) range corresponds to the maximum distance of spatial dependence; (ii) nugget effect is the y-intercept height and corresponds to a random and non-spatially correlated residual variation at the shortest sampling interval; (iii) sill is the height of the curve above its y-intercept (nugget) and corresponds to the variance due to spatial structure (Isaaks and Srivastava, 1989).

Semivariogram models often have different ranges and/or sills in different directions. For the case where only the range changes with direction, the anisotropy is known as geometric anisotropy. If only the sill changes with direction, the anisotropy is known as zonal anisotropy. The anisotropy modelling (Isaaks and Srivastava, 1989) usually starts by finding the anisotropy axes associated with the experimentally determined directions of minimum and maximum range or sill. The parameters used to interpolate the turbidity samples for each water-level stage are summarized in Table 2.

The equations representing the fitting models used to interpolate the turbidity distribution during rising (Eq. 5), high (Eq. 6), receding (Eq. 7) and low (Eq. 8) water levels are:

$$
\begin{aligned}
& \gamma(h) \\
& =619+114\left[\mathrm{Gau}\left(\sqrt{\left(\frac{h_{94^{\circ}}}{\varepsilon}\right)^{2}+\left(\frac{h_{216^{\circ}}}{16436}\right)^{2}}\right)\right] \\
& +7770\left[\mathrm{Gau}\left(\sqrt{\left(\frac{h_{94^{\circ}}}{17924}\right)^{2}+\left(\frac{h_{216^{\circ}}}{16436}\right)^{2}}\right)\right] \\
& +1480\left[\mathrm{Gau}\left(\sqrt{\left(\frac{h_{94^{\circ}}}{17924}\right)^{2}+\left(\frac{h_{216^{\circ}}}{\infty}\right)^{2}}\right)\right]
\end{aligned}
$$

$$
\begin{aligned}
& \gamma(h) \\
& =4.98+20.45\left[\mathrm{Gau}\left(\sqrt{\left(\frac{h_{100^{\circ}}}{\varepsilon}\right)^{2}+\left(\frac{h_{233^{\circ}}}{14637}\right)^{2}}\right)\right] \\
& +119.64\left[\mathrm{Gau}\left(\sqrt{\left(\frac{h_{100^{\circ}}}{12003}\right)^{2}+\left(\frac{h_{233^{\circ}}}{14637}\right)^{2}}\right)\right] \\
& +8.2\left[\mathrm{Gau}\left(\sqrt{\left(\frac{h_{100^{\circ}}}{12003}\right)^{2}+\left(\frac{h_{233^{\circ}}}{\infty}\right)^{2}}\right)\right]
\end{aligned}
$$


$\gamma(h)$

$=401+229\left[\operatorname{Exp}\left(\sqrt{\left(\frac{h_{94^{\circ}}}{\varepsilon}\right)^{2}+\left(\frac{h_{216^{\circ}}}{12402}\right)^{2}}\right)\right]$

$+3567\left[\operatorname{Exp}\left(\sqrt{\left(\frac{h_{94^{\circ}}}{16424}\right)^{2}+\left(\frac{h_{216^{\circ}}}{12402}\right)^{2}}\right)\right]$

$+261\left[\operatorname{Exp}\left(\sqrt{\left(\frac{h_{94^{\circ}}}{16424}\right)^{2}+\left(\frac{h_{216^{\circ}}}{\infty}\right)^{2}}\right)\right]$

$\gamma(h)$

$=8420+7140\left[\mathrm{Gau}\left(\sqrt{\left(\frac{h_{94^{\circ}}}{\varepsilon}\right)^{2}+\left(\frac{h_{216^{\circ}}}{6140}\right)^{2}}\right)\right]$

$+66885\left[\operatorname{Gau}\left(\sqrt{\left(\frac{h_{94^{\circ}}}{9379}\right)^{2}+\left(\frac{h_{216^{\circ}}}{6140}\right)^{2}}\right)\right]$

$+10430\left[\operatorname{Gau}\left(\sqrt{\left(\frac{h_{94^{\circ}}}{9379}\right)^{2}+\left(\frac{h_{216^{\circ}}}{\infty}\right)^{2}}\right)\right]$

where $\gamma(h)$ is the semivariance at lag $h, h_{n}$ 。 is the semivariance due to angles of anisotropy and $\varepsilon$ is the range for the lower anisotropy angle. Gau and Exp are the Gaussian and Exponential models, respectively.

\section{Results and discussion}

\subsection{Time series analysis}

Figure 4 shows the time series plot of water level, wind intensity and turbidity. The water level for the studied period shows minimum, mean and maximum values of 4.45 , 6.68 and $9.72 \mathrm{~m}$, respectively. The wind intensity time series has minimum, mean and maximum values of $0,3.16$ and $10.78 \mathrm{~ms}^{-1}$, respectively. The turbidity time series showed a standard deviation of \pm 176.5 NTU with minimum, mean and maximum values of $33.67,175.28$ and 947 NTU, respectively.

The highest values of turbidity were observed from November to the first half of December (2004). From the second half of December to April (2005) the turbidity was relatively small, showing a slowly decreasing trend. Turbidity peaks were also observed during this period of low turbidity. The smallest values occurred from March to April 2005.

The variability of the turbidity time $f(t)$ can be modelled by the following eight-term Gaussian series:

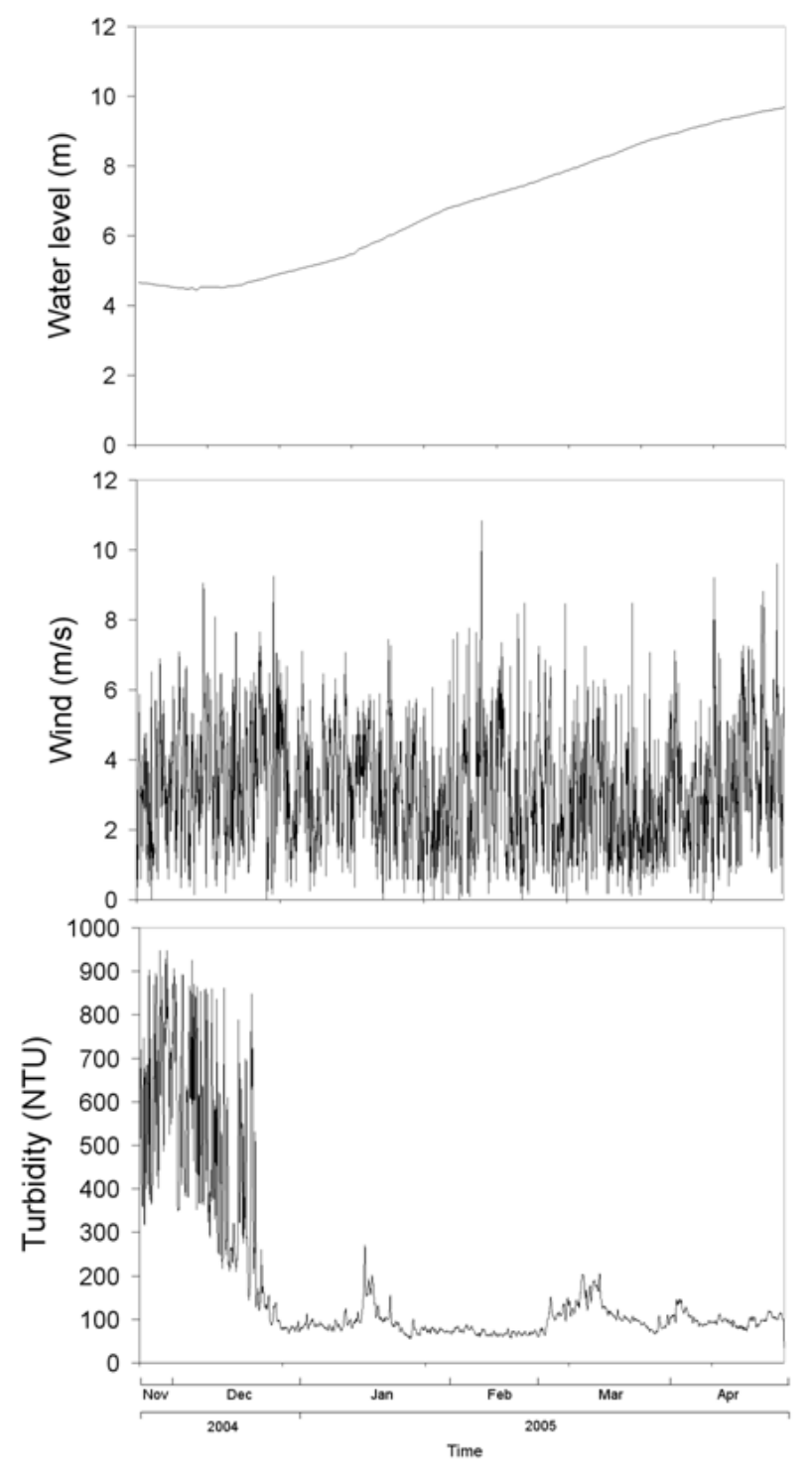

Fig. 4. Time series of water level (m), wind intensity $\left(\mathrm{ms}^{-1}\right)$ and turbidity (NTU).

$$
\begin{aligned}
& f(t) \\
& =h \exp \left(-\left(\frac{t-\mu}{\sigma}\right)^{2}\right)+386.6 \exp \left(-\left(\frac{t-106}{44.57}\right)^{2}\right) \\
& +456 \exp \left(-\left(\frac{t-187}{33.91}\right)^{2}\right)-428.2 \exp \left(-\left(\frac{t-317.9}{35.99}\right)^{2}\right) \\
& +642.3 \exp \left(-\left(\frac{t-308.7}{91.08}\right)^{2}\right)+102.4 \exp \left(-\left(\frac{t-802.5}{32.56}\right)^{2}\right) \\
& +80.17 \exp \left(-\left(\frac{t-1571}{85.59}\right)^{2}\right)+87.4 \exp \left(-\left(\frac{t-1458}{22.77}\right)^{2}\right)
\end{aligned}
$$

where $(h)$ is the amplitude, $(t)$ is time, $(\mu)$ is the central or peak position and $(\sigma)$ is the variance. 


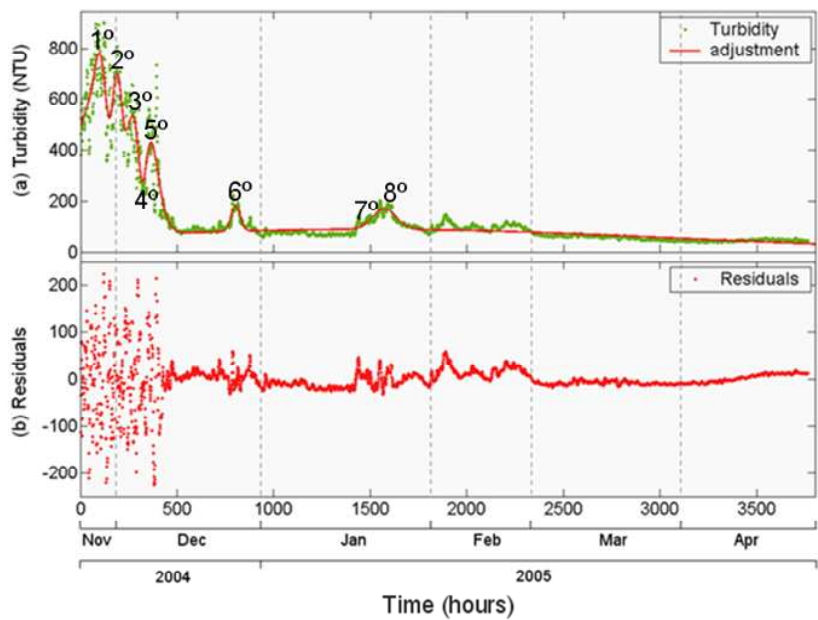

Fig. 5. Turbidity time series and Gaussian model using the eightterm series (Eq. 9) (upper panel). Model residuals (lower panel).

Figure 5 shows the location of all Gaussian terms in Eq. 9. The first Gaussian-term represents the variability of the turbidity in November with a standard deviation (std) of 105.20 (NTU), which was the highest value of the whole series. The second term represents the transition between November and December with a std of 44.57 NTU. The third represents the turbidity variability in the beginning of December (std of 33.91 NTU). The fourth term shows a negative amplitude, representing an abrupt decrease in turbidity values (std of $35.99 \mathrm{NTU}$ ). The fifth term shows an increase of turbidity in December, also with an increase of a std to 91.08 NTU. The sixth presents the Gaussian model for the end of December. The seventh and eighth represent the January peaks (beginning of the rising water level). Note that from February to April the fitting does not find any other Gaussian term. This is because the turbidity in these months is very low and without great peaks, as opposed to the peaks during November and December (low-water level).

The adjustment of this model to the data can be seen in Fig. 5. Although the fitting is reasonably good in the mean, during the high variability period from November to December of 2004 the model fitting did not capture all the variability. This is highlighted in Fig. 5b by the high residuals during this period. From the second half of December to April the fitting works very well. The overall fitting was $R^{2}=0.94$ $(p=0.05$ and $\mathrm{RMSE}=36.2$ ). This pattern of variability will be analysed by Fourier and wavelet analysis.

In general, the turbidity time series shows the response of the Curuai floodplain to the flood pulses (Alcântara, 2006). The highest values of turbidity occurred in the low-water level, which may be attributable to sediment resuspension events caused by the waves generated by sufficiently high winds.

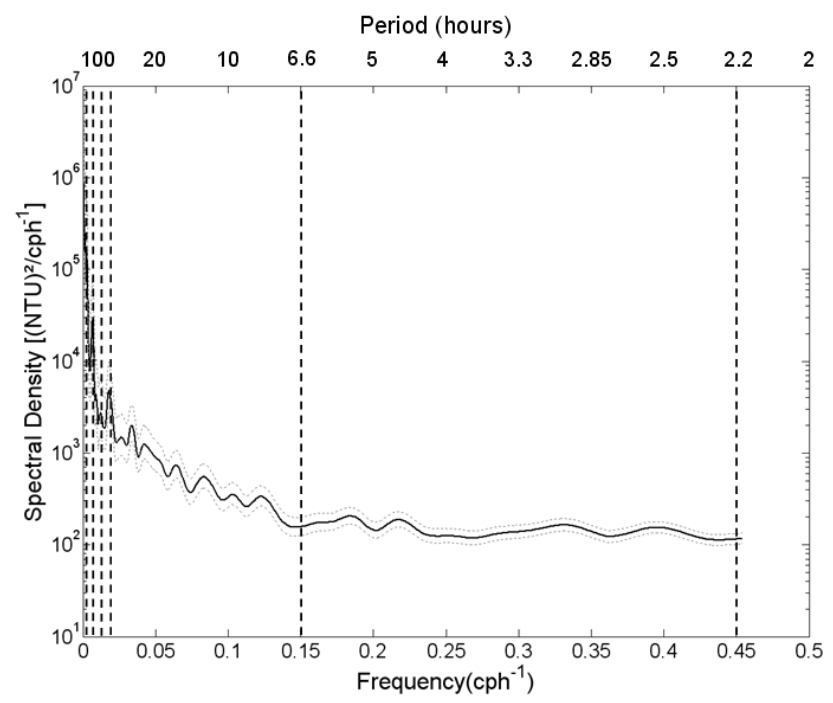

Fig. 6. Fourier power spectrum of the turbidity time series. The dashed lines represent the $95 \%$ confidence interval limits.

The Fourier power spectrum (Fig. 6) shows that the highest spectral density occurs from between 90 to $120 \mathrm{~h}$ (3.75-5 days). From this point the spectral density falls, and pronounced peaks occur at 80 and $30 \mathrm{~h}$ (3.3-1.25 days). The spectral density is very small for frequencies from 0.15 to $0.45 \mathrm{cph}^{-1}(6.6-2.2 \mathrm{~h})$.

All these peaks occur from November (2004) to December (2005). This is due to the high variability of turbidity during this period (Fig. 5). For more detail about the localized time frequency, the wavelet analysis is more suitable.

The wavelet analysis shown in Fig. 7 reveals that in November 2004 the period of high variability is from 8 to $512 \mathrm{~h}$ ( $\sim 21$ days), while below this the periods are not significant within the 95\% confidence level (separated by the cone of influence). Up to December 2004 the periods increase until $2048 \mathrm{~h}$ ( $\sim 85$ days), with peaks in the end of this month between 16-64h ( $\sim 2$ days). From January to February 2005 the period increases until 4096 h ( 170 days). From March to April 2005 the periods increase again until $1024 \mathrm{~h}$ (42 days), without periods smaller than $128 \mathrm{~h}$ ( $\sim 5$ days).

In fact, the short periods showing in November and December 2004 are due to the high variability of turbidity events. Also, on the other hand, the greater periods from January to April 2005 are due to small variations in turbidity events.

The high mean values and standard deviations of turbidity in the low-water level regime are caused mainly by wind action. In the Curuai floodplain, the wind speed can reach $10 \mathrm{~ms}^{-1}$ (see Fig. 8). The wind stress induces an energetic wave-affected layer in which both large-scale orbital movements and the dissipated turbulent energy are important. The proximity of the surface and bottom boundaries in shallow 


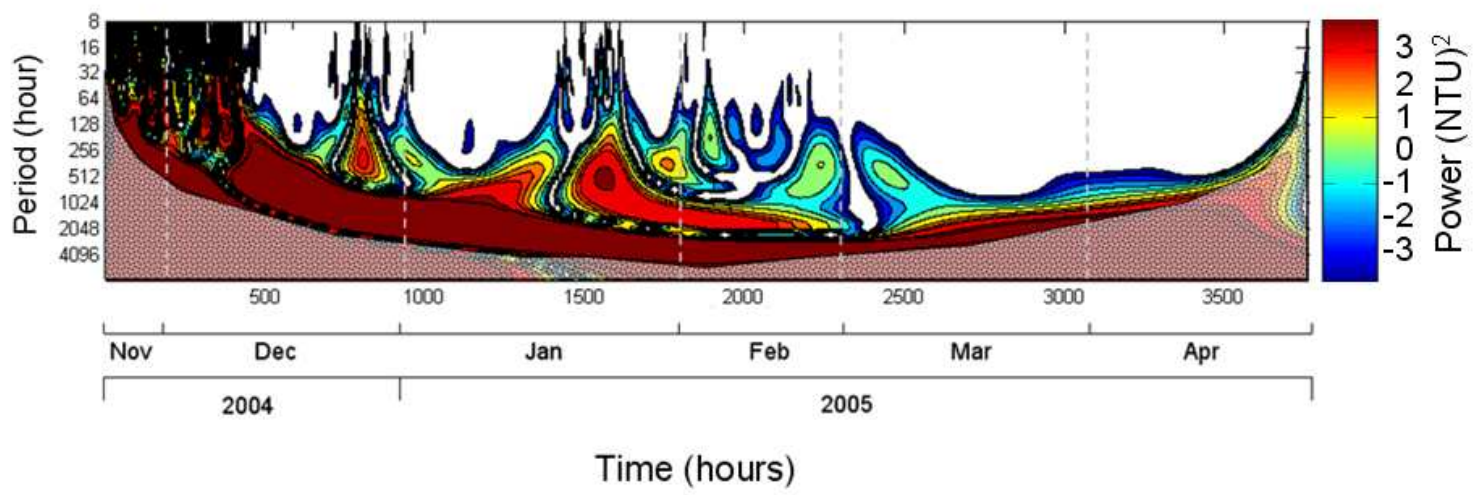

Fig. 7. Wavelet analysis of the turbidity time series. Cross-hatched regions on either end indicate the "cone of influence", where edge effects become important.

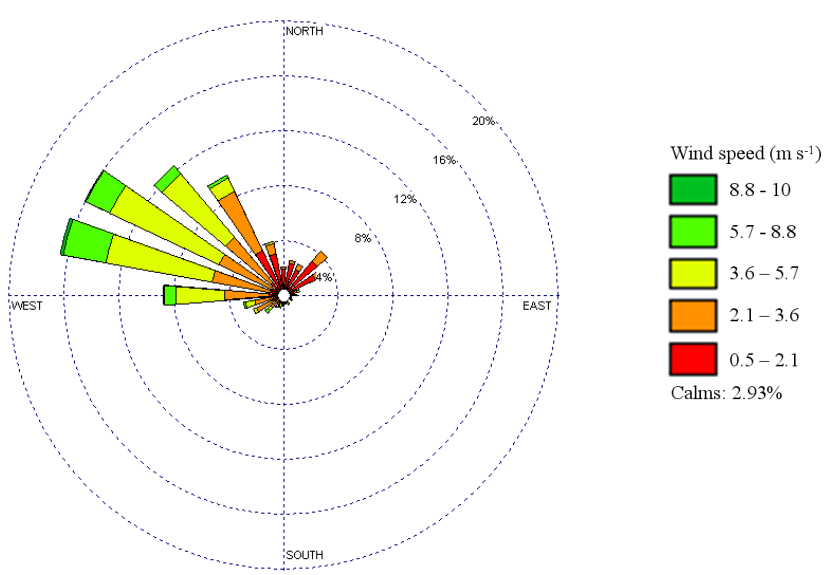

Fig. 8. Wind rose diagram of data collected by SIMA from 20 November 2004 to 3 April 2005.

lakes often generates a completely mixed water column during the resuspension events (Booth et al., 2000; Cózar et al., 2005). During the observational period, the winds acquired by SIMA at "Lago Grande" varied from 0.2 to $10 \mathrm{~ms}^{-1}$, with a preferential direction from southeast to northwest (Fig. 8).

To check the possible causes of sediment resuspension during the low-water level (November, December and January), we will apply the critical wave period (CERC, 1984). Our analysis of the suitability of wind to cause resuspension in the high-water level was supported by Novo et al. (2006), who showed a rate less than $0.2 \mathrm{~cm} \mathrm{~h}^{-1}$ of water level change.

We checked this for November (2004), event E1, when the variability is larger than that in the other months of the whole time series, as well as for December (2004), event E2, when the variability is smaller than that in November and January (2005), and event E3, where the peaks of variability are more feasibly able to separate due to the rare events of high turbidity.
Table 3. Critical wind speed $\left(\mathrm{ms}^{-1}\right)$ limits to cause bottom sediment resuspension.

\begin{tabular}{lccc}
\hline Depth $(\mathrm{m})$ & Events & Fetch $(\mathrm{m})$ & $\mathrm{Uc}\left(\mathrm{ms}^{-1}\right)$ \\
\hline 1.38 & E1 & 33000 & 0.44 \\
1.60 & E2 & 11556 & 1.04 \\
2.32 & E3 & 10300 & 1.14 \\
\hline
\end{tabular}

The first event (E1) corresponds to the low-water level, event $\mathrm{E} 2$ corresponds to the flow of water from the floodplain to the Amazon River and event E3 takes place when the water level begins to rise in response to the water flowing into the floodplain from the Amazon River.

Events E1, E2 and E3 can probably be attributed to the combination of high wind intensity and shallow-water level. In agreement with Carper and Bachmann (1984), the surface waves produced when wind blows across the surface water cause the bottom resuspension and temporarily increase the turbidity.

Event E1 has minimum, mean and maximum wind velocities of $0.59,5.47$ and $9.02 \mathrm{~ms}^{-1}$ and a preferential wind direction from northwest to southeast (Fig. 9a). Event (E2) has minimum, mean and maximum wind velocities of $1.98,4.5$ and $5.75 \mathrm{~ms}^{-1}$, with a preferential wind direction from northwest to southeast, during 24-h (Fig. 9b). Event E3 has minimum, mean and maximum wind velocities of $0.34,2.37$ and $5.95 \mathrm{~ms}^{-1}$, with a preferential wind direction from northwest to southeast, during 24-h (Fig. 9c).

The critical wind speed $\left(\mathrm{ms}^{-1}\right)$ for event E1 is 0.44 and for E2 is 1.04 (Table 3). For event E3 the critical wind speed is $1.14\left(\mathrm{~ms}^{-1}\right)$. Wind speeds above these values are suitable for the bottom resuspension in the SIMA location, so both E1 and E2 are suitable for wind-induced bottom resuspension. 


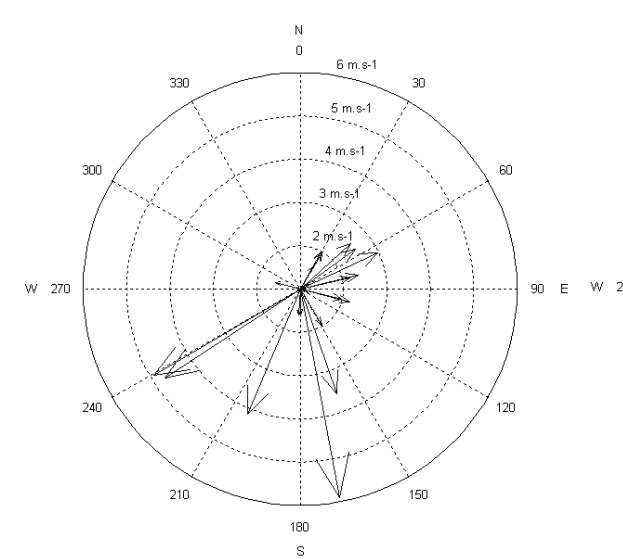

(a)

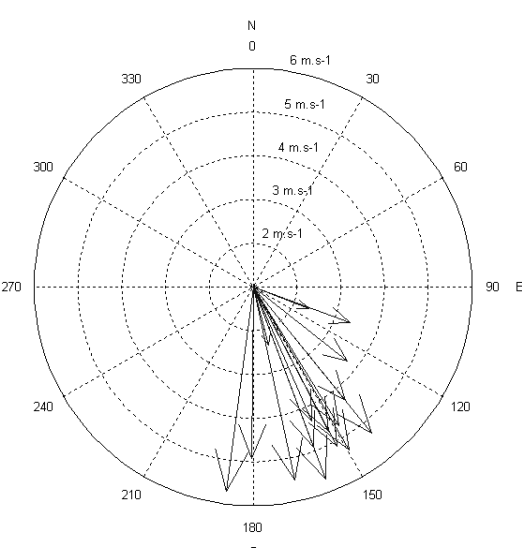

(b)

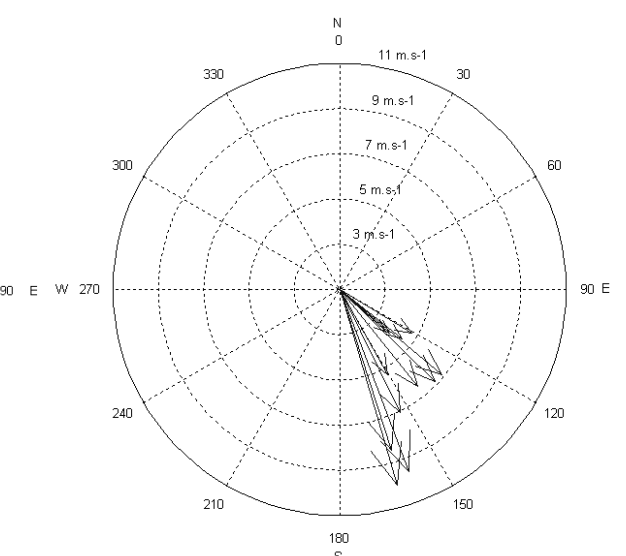

(c)

Fig. 9. Compass wind roses of events E1 (a), E2 (b) and E3 (c).

In Event E1, the peaks of high turbidity and low turbidity mark an incidence of unusually low turbidity in the lowwater level, in spite of the wind speed being above the critical threshold at which sediment resuspension can occur. However, this could be due to the duration of the minimum wind speed $\left(0.59 \mathrm{~ms}^{-1}\right)$ registered by SIMA being low when compared with the time series in this water stage. As a consequence, a decantation of suspended solids occurs due to the end of the wind action in the surface water.

In accordance with Moreira-Turcq et al. (2004), the silt and clay dominate the suspended solids in the Curuai floodplain (87-98\%), and the decrease of the current velocity occurring at the end of wind action causes particle settling. In the low-water stage, the depositional processes in the lakes and channels are disrupted by the wind-induced resuspension of sediments (Maurice-Bourgoin, 2007) and bioturbation in shallow lakes (Maia et al., 2008).

To investigate this relationship, we use a cross-wavelet and coherence analysis to register the importance of wind action on turbidity behaviour. Wavelet coherency is a measure of the intensity of the covariance of the two time series in timefrequency space, unlike the cross-wavelet power as a measure of the common power.

\subsection{Cross-wavelet spectrum and wavelet coherence and phase}

In Fig. 10a and b, we present the cross-wavelet spectrum and coherency spectrum, respectively. Horizontal arrows indicate a simple linear relationship between turbidity and wind action. Arrows pointing to the right mean correlation (in phase), and an anticorrelation (in antiphase) is indicated by a left-pointing arrow. Non-horizontal arrows refer to a more complicated (nonlinear) phase difference (ValdésGalicia and Velasco, 2008).
The cross wavelet spectrum between the turbidity and wind intensity time series shows a high agreement in the first $500 \mathrm{~h}$ ( $\sim 20$ days, from 20 November 2004 to 10 December 2005) for periods from 4 to $200 \mathrm{~h}$ ( $\sim 8$ days) (see Fig. 10a). These results confirm our findings about the importance of the wind action on surface water in enhancing the turbidity during the low-water level.

The coherence is high for this first $500 \mathrm{~h}$, mainly in periods of 4,8 and $19 \mathrm{~h}$. This coherence in the low time frequency is due to the sediment resuspension caused by wind, as shown in Table 3 (Fig. 10b). The arrows presented in these periods are non-horizontal, representing a complicated, nonlinear phase difference.

The agreement between turbidity and wind decreases with rising water levels, in which the wind does not cause as much sediment resuspension. As pointed out by Alcântara (2006), in high-water levels the turbidity values are low due to fine sediment decantation. Therefore, the high agreement migrates for higher periods (Fig. 10a), following the water level dynamics. Also, the coherence migrates too (Fig. 10b). These influences of wind action and water-level dynamics influence not only the time series domain but also the whole lake.

To investigate the differences in turbidity between the various lakes in the Curuai floodplain, the spatial turbidity distribution over the entire floodplain is determined by applying the ordinary Kriging algorithm on the turbidity collected in situ by a HORIBA U-10 multi-sensor.

\subsection{Spatial analysis}

Using a scatterplot, the performance of the ordinary Kriging to interpolate the in situ turbidity data was evaluated for each sampling campaign (Fig. 11). The performance of all interpolated in situ turbidity data was statistically satisfactory and reliable. The most accurate interpolation was the one made 

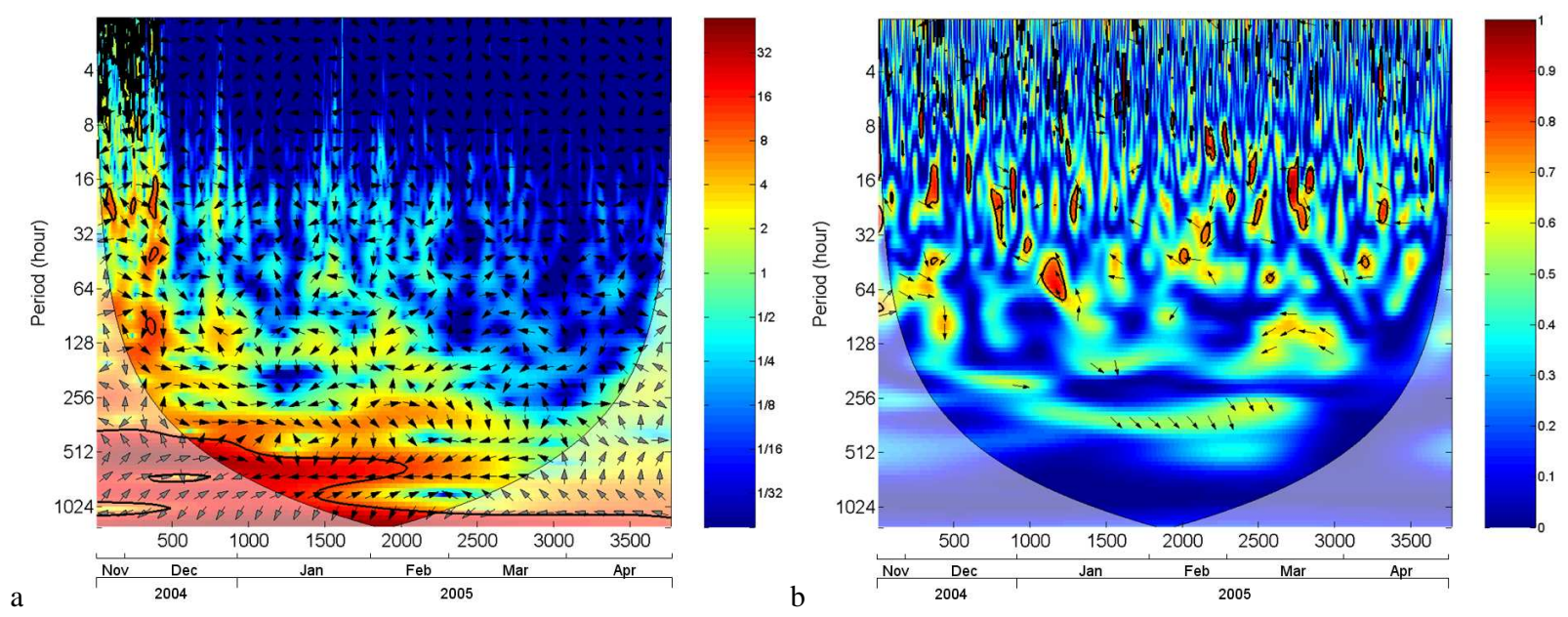

Fig. 10. (a) Cross-wavelet transformation of the standardized turbidity and wind intensity time series. The 5\% significance level against red noise is shown as a thick contour. The relative phase relationship is shown with the arrows. (b) Squared wavelet coherence between the standardized turbidity and wind intensity time series. The 5\% significance level against red noise is shown as a thick contour.

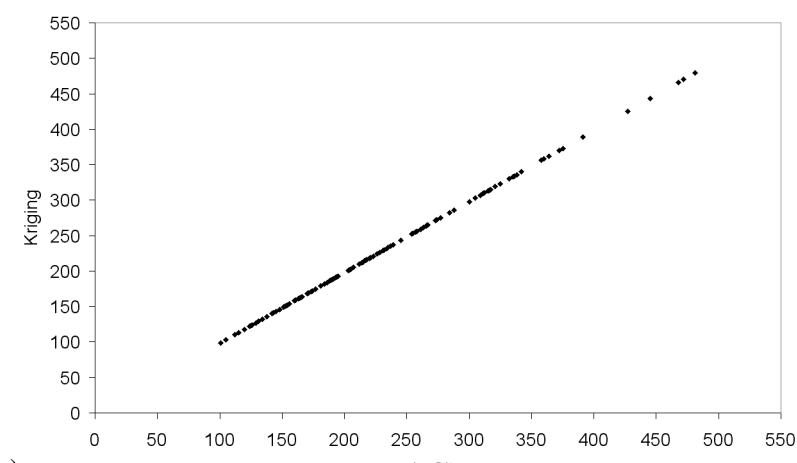

(a)

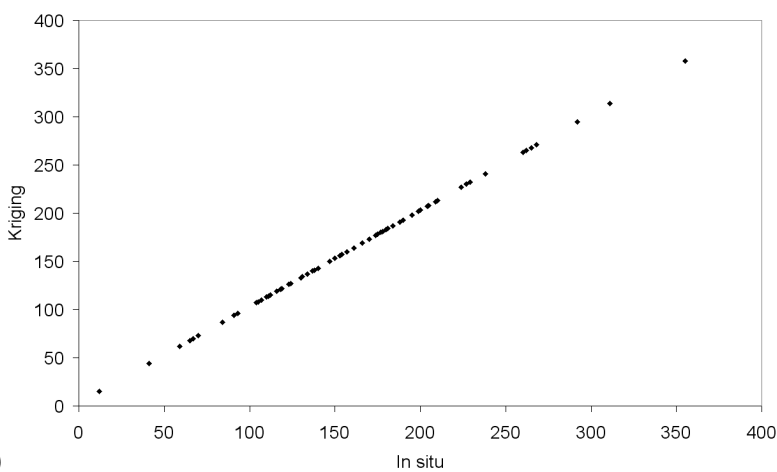

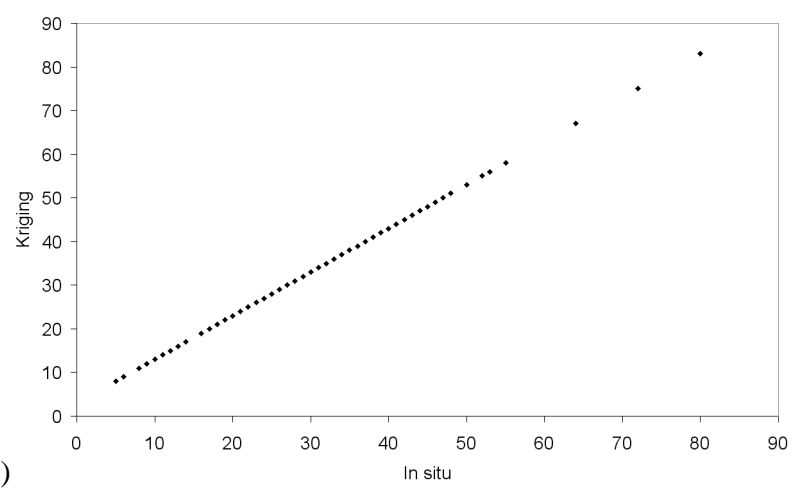

(b)

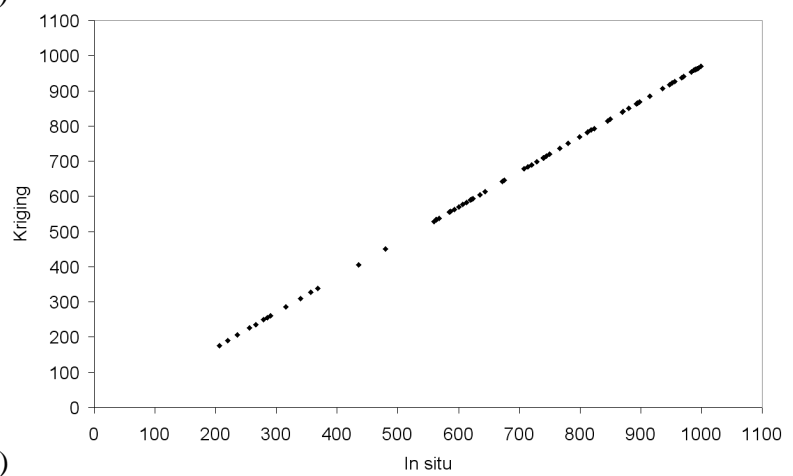

Fig. 11. Performance of each interpolated turbidity data: (a) during rising, (b) high, (c) receding and (d) low-water levels.

for the data in the high-water level regime (RMSE=3 NTU), while the interpolation for the low-water level regime was the least accurate (RMSE=25 NTU).

This is a result of the water level stability and low standard deviation in the high-water level regime (mean $=31.46$, see Fig. 3d), as well as the high standard deviation (mean=771.11, see Fig. 3b) and sediment resuspension events in the low-water level regime (see Table 3 ).
All in situ turbidity data were interpolated using the ordinary Kriging algorithm to assess the turbidity distribution and variability in response to flood pulses (Fig. 12). According to Bonnet et al. (2008), the water storage within the floodplain started between December and February and lasted until June. From this time until the end of the water year, water was exported from the floodplain into the river, with the maximum water export occurring from August to September. 


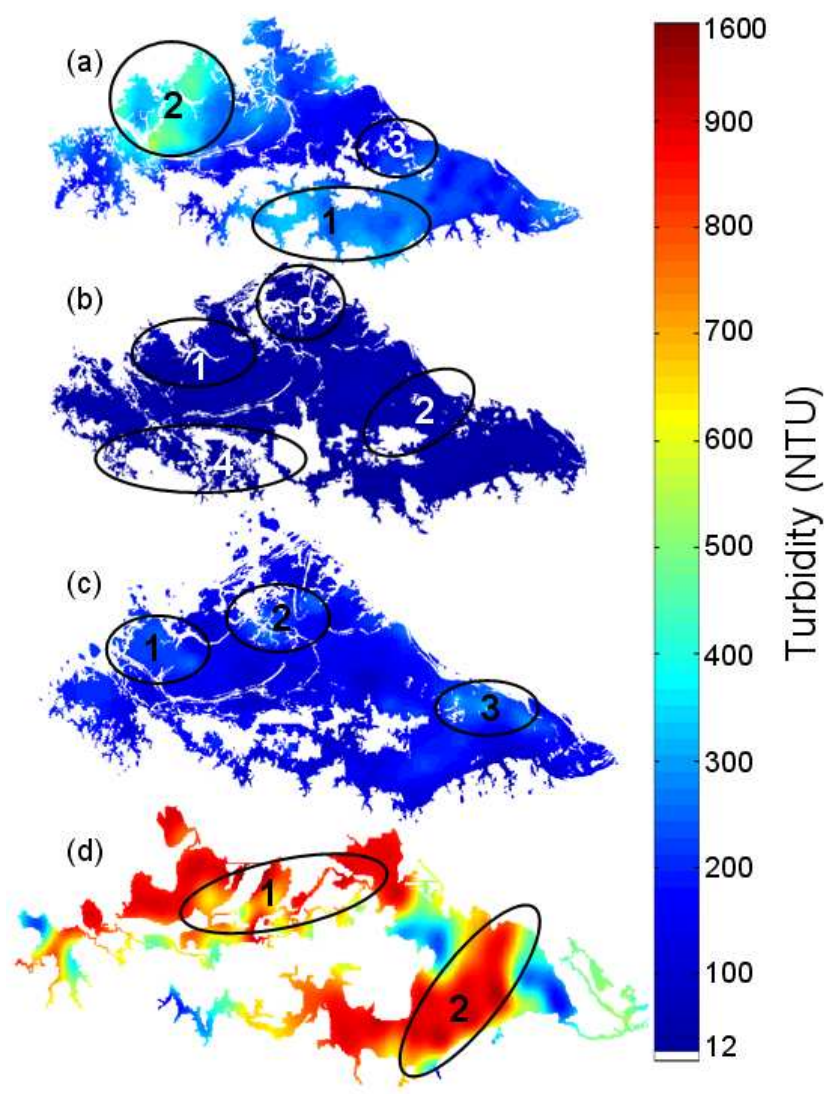

Fig. 12. Ordinary Kriging maps: (a) turbidity distribution (NTU) during rising, (b) high, (c) receding and (d) low-water levels.

The semivariogram for the turbidity data during rising, high- and low-water levels was best described by a Gaussian model, indicating a smoothly varying pattern in turbidity distribution. During receding water levels, the semivariogram was best represented by an exponential function, suggesting a dataset with a spatial pattern characterised by gradual transition among several patterns interfering with each other (Burrough and Mcdonnell, 1998) (see Table 2).

In the rising water level regime (Fig. 12a), the flow from the Amazon River to the Curuai floodplain starts in a channel located at the eastern border of the lake, and then it migrates to small channels at the northwestern border (Alcântara et al., 2009). The yellow circle 1 marks a region of high turbidity formed by the water from the Amazon River entering through the channel located at the eastern border. The region of high turbidity marked by the yellow circle 2 was formed by water entering through the small channels located on the northwestern side. The yellow circle 3 marks a region of low turbidity.

In the high-water level regime (Fig. 12b), the input of water from the Amazon River is lowest and the turbidity tends to be spatially homogeneous (Alcântara et al., 2008). The areas of high turbidity (marked 1 and 2) correspond to the small channels connecting the floodplain with the Amazon River. Area 3 also corresponds to a connecting channel, however, its turbidity is low. This probably occurs because this channel is the first to cease flowing water into the floodplain. Area 4 has a low turbidity due to the forest cover, favouring a decrease in flow velocity and particle settling because of lower hydrodynamics.

In the receding water level regime (Fig. 12c), the preferential direction of flow is from west to east (Barbosa, 2005). As a result, the regions marked 1 and 2 in Fig. 12c show a high turbidity due to the friction of water at the channel borders. The high turbidity in area 3 stems from suspended solids entering from the east channel connected to the Amazon River. The receding water level stage causes a condition of turbulent flow, thereby leading to increased turbulence.

In the low-water level regime (Fig. 12d), the exchange between the Amazon River and the Curuai floodplain reaches a minimum, and the turbidity variability is mainly winddriven. As discussed above, the preferential wind direction is from southeast to northwest (Fig. 8), causing water to pile up and generate a dowelling near the channel margins and an upwelling in the opposite direction. These regions are marked by the yellow circles 1 and 2 .

\section{Conclusions}

This result shows the importance of high-frequency and spatial data in limnological studies of complex aquatic systems (i.e., the Amazon floodplain), in contrast to conventional studies with only occasional sampling that can lead to the misinterpretation of the turbidity behaviour.

The flood pulse that occurs with the rising waters of the Amazon flood introduces turbidity from 80 to 180 NTU. During the low-water period the wind stirs up the bottom sediments, leading to turbidities in excess of 1100 NTU. Therefore, the highest turbidities and the greatest variability are caused by wind blowing over shallow water. The analysis of the spatially distributed turbidity samples with the ordinary Kriging algorithm showed the same dependence on water level and wind observed by SIMA in the time series in a single sampling point.

The Fourier power spectrum reveals peaks of high spectral density from 3.75 to 5 days and small spectral density from 2 to $6.6 \mathrm{~h}$. The wavelet analysis locates this on the timefrequency domain. During low-water levels, the high turbidity variability occurs from 21 to 85 days. However, peaks of 2 days can occur in association with re-suspension events. In rising water levels, these periods rise to 170 days in the beginning of the stage, and from the middle to the end the periods of variability are lower (from 5 to 42 days). The cross wavelet analysis confirms the results obtained by the Fourier and Wavelet analysis, showing that, during low-water levels, the high common power occurs for periods less than 2.66 days and the period rises as the water level rises. 
The only water level stage lacking simultaneously acquired SIMA time series and spatially distributed data was the high-water period. However, the time variability during the high-water period is small due to the inhibition of sediment re-suspension by the weak winds and sediment settling. The information on the sediment behaviour of the floodplain during high water was captured by the spatial data analysis.

Spatially distributed and time series limnological data should be viewed as complimentary. The lack of a high temporal resolution time series may result in severe under sampling. For example, quick but important events of resuspension might be not observed at all. Also, the availability of ancillary meteorological time series help to elucidate important relationships between sediment concentration and forcing, such as those demonstrated in this paper. On the other hand, spatial maps allow a better view of the patterns of variability throughout the floodplain. This is particularly important in such complex systems as the Curuai. When feasible, spatial and temporal data should be used together for more accurate results.

Acknowledgements. The authors are grateful to the Brazilian funding agency FAPESP under grants 02/09911-1 and the Brazilian Council for Scientific and Technological Development (CNPq) for the M.Sc fellowship to E. H. Alcântara. We also thank C. Torrence and G. Compo for providing the Wavelet software available at http://atoc.colorado.edu/research/wavelets/, as well as A. Gristed for providing the cross-wavelet and wavelet coherence algorithm software available at http://www.pol.ac.uk/home/research/waveletcoherence/.

Edited by: A. Ghadouani

\section{References}

Alcântara, E. H.: Analysis of turbidity in Curuai floodplain through the integration of telemetric and MODIS/Terra image data (MSc. Dissertation), INPE: São José dos Campos, Brazil, 220 pp., 2006 (in Portuguese).

Alcântara, E. H., Stech, J. L., Novo, E. M. L. M., Shimabukuro, Y. E., and Barbosa, C. C. F.: Turbidity in the Amazon floodplain assessed through a spatial regression model applied to fraction images derived from MODIS/Terra. IEEE Trans. Geo. Rem. Sens. 46, 2895-2905, 2008.

Alcântara, E. H., Barbosa, C. C. F., Stech, J. L., Novo, E. M. L. M., and Shimabukuro, Y. E.: Improving the spectral unmixing algorithm to map water turbidity distributions. Environ. Modell. Softw., 24, 1051-1061, 2009.

Barbosa, C. C. F.: Sensoriamento remoto da dinâmica de circulação da água do sistema planície de Curuai/ Rio Amazonas (PhD. Thesis), INPE: São José dos Campos, Brazil, 255 pp., 2005.

Barroux, G.: Bio-geochemical study of a lake system from the Amazonian floodplain: the case of "Lago Grande de Curuaî", Pará-Brazil (PhD Thesis), UPS: Toulouse, France, 304 pp., 2006 (in French).
Bellehumeur, C., Marcotte, D., and Legendre, P.: Estimation of regionalized phenomena by geostatistical methods: lake acidity on the Canadian Shield, Environ. Geol., 39, 211-220, 2000.

Bonnet, M. P., Barroux, G., Martinez, J. M., Seyler, F., MoreiraTurcq, P., Cochonneau, G., Melack, J. M., Boaventura, G., Maurice-Bourgoin, L., León, J. G., Roux, E., Calmant, S., Kosuth, P., Guyot, J. L., and Seyler, P.: Floodplain hydrology in an Amazon floodplain lake (Lago Grande de Curuaí), J. Hydrol., 349, 18-30, 2008.

Booth, J. G., Miller, R. L., McKee, B. A., and Leathers, R. A.: Wind-induced bottom sediment resuspension in a microtidal coastal environment, Cont. Shelf Res., 20, 785-806, 2000.

Burrough, P. A.: GIS and Geostatistics: Essential partners for spatial analysis. Environ. Ecol. Stat. 8, 361-377, 2001.

Burrough, P. A. and Mcdonnell, R. A.: Principles of geographical information systems, 2rd Ed., Oxford University Press, New York, USA, 356 pp., 1998.

Carper, G. L. and Bachmann, R. W.: Wind resuspension of sediments in a prairie lake, Can. J. Fish. Aquat. Sci. 41, 1763-1767, 1984.

CERC: Shore protection manual, 1rd Ed, US Army Coastal Engineering Center, Viksburg, USA, 603 pp., 1984.

Cózar, A., Gálvez, J. A., Hull, V., García, C. M., and Loiselle, S. A.: Sediment resuspension by Wind in a shallow lake of Esteros Del Iberá (Argentina): a model based on turbidimetry, Ecol. Model. 186, 63-76, 2005.

De Leo, G. A. and Ferrari, I.: Disturbance and diversity in a river zooplankton community: a neutral model analysis, Coenoses., 8 , 121-129, 1993.

Dekker, A. G., Vos, R. J., and Peters, S. W. M.: Analytical algorithms for lake water TSM estimation for retrospective analyses of TM and SPOT sensor data, Int. J. Remote Sens. 23, 15-35, 2002.

Farge, M.: Wavelet transforms and their applications to turbulence, Annu. Rev. Fluid Mech. 24, 395-457, 1992.

George, D. G.: The airborne remote sensing of phytoplankton chlorophyll in the lakes and tarns of the English Lake District, Int. J. Remote Sens. 18, 1961-1975, 1997.

Goovaerts, P.: Geostatistics for natural resources evaluation, Oxford University Press, New York, USA, 483 pp., 1997.

Grinsted, A., Moore, J. C., and Jevrejeva, S.: Application of the cross wavelet transform and wavelet coherence to geophysical time series, Nonlinaer Proc. Geoph. 11, 561-566, 2004.

Han, L. and Rundquist, D. C.: The impact of a wind-roughened water surface on remote measurements of turbidity, Int. J. Remote Sens. 19, 195-201, 1998.

Hedger, R. D., Atkinson, P. M., and Malthus, T. J.: Optimizing sampling strategies for estimating mean water quality in lakes using geostatistical techniques with remote sensing, Lakes \& Reservoirs, Res. Manage., 6, 279-288, 2001.

Isaaks, E. H. and Srivastava, M. R.: An introduction to applied geostatistics, Oxford University Press, New York, USA, 561 pp., 1989.

Jerosch, K., Schlüter, M., and Pesch, R.: Spatial analysis of marine categories information using indicator Kriging applied to georeferenced video mosaics of the deep-sea Håkon Mosby Mud Volcano, Ecol. Inform., 1, 391-406, 2006. 
Junk, W. J.: The Central Amazon Floodplain: ecology of a pulsing system, 1rd Ed., Springer Verlag, Berlin, Germany, 525 pp., 1997.

Justus, C. G. and Mikhail, A.: Height variation of wind speed and wind distribution statistics, Geophys. Res. Lett., 3, 264-264, 1976.

Kirk, J. T. O.: Light and photosynthesis in aquatic environments, 1rd Ed., Cambridge University Press, Cambridge, USA, 401 pp., 1983.

Kumar, P. and Foufoula-Georgiou, E.: Wavelet analysis for geophysical application, Rev. Geophys., 35, 385-412, 1997.

Lima, I. B. T., Carvalho, J. C., Ramos, F. M., Rosa, R. R., Sych, R. A., and Novo, E. L. M. M.: Detecting climatic and tidal influence on the Amazon River level by wavelet analysis, Int. Ver. The., 29, 1785-1788, 1995.

Lou, J., Schwab, D. J., Beletsky, D., and Hawley, N.: A model of sediment resuspension and transport dynamics in southern Lake Michigan, J. Geophys. Res., 105, 6591-6610, 2000.

Maia, P. D., Maurice, L., Cossa, D., Portugal, R. A., Etcheber, H., Souza, J. R., Guimarães, E. M., and Boaventura, G. R.: Is the Curuai floodplain (Middle Amazon, Brazil) an efficient trap for particulate mercury?, Geophys. Res. Abstr., 10, 12238, 2008.

Martinez, J.-M. and Le-Toan, T.: Mapping of flood dynamics and spatial distribution of vegetation in the Amazon floodplain using multitemporal SAR data, Remote Sens. Environ. 108, 209-223, 2006.

Maraun, D. and Kurths, J.: Cross wavelet analysis: significance testing and pitfalls, Nonlinear Proc. Geophy., 11, 505-514, 2004.

Massei, N., Dupont, J. P., Mahler, B. J., Laignel, B., Fournier, M., Valdes, D., and Ogier, S.: Investigating transport properties and turbidity dynamics of a karst aquifer using correlation, spectral, and wavelet analyses, J. Hydrol., 329, 244-257, 2006.

Maurice-Bourgoin, L., Bonnet, M. P., Martinez, J. M., Kosuth, P., Cochonneau, G., Moreira-Turcq, P., Guyot, J. L., Vauchel, P., Filizola, N., and Seyler, P.: Temporal dynamics of water and sediment exchanges between the Curuaí floodplain and the Amazon River, Brazil, J. Hydrol., 335, 140-156, 2007.

Meade, R. H., Dunne, T., Richey, J. E., Santos, U. M., and Salati, E.: Storage and remobilization of suspended sediment in the lower Amazon River of Brazil, Science, 228, 488-490, 1985.

Moreira-Turcq, P. F., Jouanneau, B., Turcq, B., Seyler, P., Weber, O., and Guyot, J. L.: Carbon sedimentation at Lago Grande de Curuaí, a floodplain lake in the low Amazon region: insight into sedimentation rates, Palaeogeogr. Palaeocl., 214, 27-70, 2004.

Meyers, S. D., Kelly, B. G., and O'Brien, J. J.: An introduction to wavelet analysis in Oceanography and Meteorology: with application to the dispersion of Yanai Waves, Mon. Weather Rev., 121, 2858-2866, 1993.

Mertes, L. A. K., Dunne, T., and Martinelli, L. A.: Channelfloodplain geomorphylogy along the Solimões-Amazon River, Brazil, GSA Bulletin, 108, 1089-1107, 1996.
Miquelis, A., Rougier, C., and Pourriot, R.: Impact of turbulence and turbidity on the grazing rate of the rotifer Brachionus calyciflorus (Pallas), Hydrobiologia, 386, 203-211, 1998.

Newcombe, C. P. and Jensen, J. O. T.: Channel suspended sediment and fisheries: a synthesis for quantitative assessment of risk and impact, N. Am. J. Fish. Manage., 16, 693-727, 1996.

Novo, E. L. M. M., Barbosa, C. C. F., Freitas, R. M., Shimabukuro, Y. E., Melack, J. M., and Pereira-Filho, W.: Seasonal changes in chlorophyll distribution in Amazon floodplain lakes derived from MODIS images, Limnology, 7, 153-161, 2006.

Press, W. H., Teukolsky, S. A., Vetterling, W. T., and Flannery, B. P.: Numerical recipes in fortran 77: the art of scientific computing. Vol. 1 of Fortran numerical recipes, Cambridge University Press, UK, 933 pp., 1992.

Roozen, F. C. J. M., Van-Geest, G. J., Ibelings, B. W., Roijackers, R., Scheffer, M., and Buijse, A. D.: Lake age and water level affect the turbidity of floodplain lakes along the lower Rhine, Freshwater Biol., 48, 519-531, 2003.

Stech, J. L. and Lorenzzetti, J. A.: The response of the south Brazil bight to the passage of wintertime cold fronts, J. Geophys. Res., 97, 9507-9520, 1992.

Stech, J. L., Lima, I. B. T., Novo, E. M. L. M., Silva, C. M., Assireu, A. T., Lorenzzetti, J. A., Carvalho, J. C., Barbosa, C. C. F., and Rosa, R. R.: Telemetric Monitoring System for meteorological and limnological data acquisition, Verh. Internat. Verein. Limnol. 29, 1747-1750, 2006.

Stevens, C. and Imberger, J.: The initial response of a stratified lake to a surface shear stress, J. Fluid Mech. 312, 39-66, 1996.

Tundisi, J. G., Matsumura-Tundisi, T., Arantes-Junior, J. D., Tundisi, J. E. M., Manzini, N. F., and Ducrot, R.: The response of Carlos Botelho (Lobo, Broa) reservoir to the passage of cold fronts as reflected by physical, chemical and biological variables, Braz. J. Biol., 64, 177-186, 2004.

Torrence, C. and Compo, G. P.: A Practical Guide to Wavelet Analysis, B. Am. Meteorol. Soc., 79, 61-78, 1998.

Torrence, C. and Webster, P.: Interdecadal changes in the ENSOMonsoon system, J. Climate. 12, 2679-2690, 1999.

Tyler, A. N., Svab, E., Preston, E., Présing, M., and Kovács, W. A.: Remote sensing of the water quality of shallow lakes: A mixture modelling approach to quantifying phytoplankton in water characterized by high-suspended sediment, Int. J. Remote. Sens., 27, 1521-1537, 2006.

Valdés-Galicia, J. F. and Velasco, V. M.: Variations of mid-term periodicities in solar activity physical phenomena, Adv. Space Res., 41, 297-305, 2008.

Wetzel, R. G.: Limnology - Lake and River Ecosystems, 3rd Ed., Academic Press, San Diego, USA, 1006 pp., 2001.

Zhang, Y., Pulliainen, J. T., Koponen, S. S., and Hallikainen, M. T.: Water quality retrievals from combined Landsat TM data and ERS-2 data in the Gulf of Finland, IEEE Trans. Geosci. Remote, 41, 622-629, 2003. 